
operation determines in many aspects the reliability of nuclear power plant (NPP) operation as a whole. The control of all heat-mass exchange processes in power engineering is performed by the valves that are included practically into every system of the plant and function as the key and responsible NPP equipment. One of the most important features of power valves is their tightness.

\title{
Experimental Research
} of Valve Tightness at Different Closure Forces

\begin{abstract}
Power valves are installed on almost all the pipelines of nuclear power plants performing the functions of regulation and shutting off the flow, so its failure often leads to emergencies. A particularly large number of failures is observed in motor-operated valves. Incorrect setting of the limiting clutch leads either to incomplete closure of the valve or to rod failure. Therefore, the valves are equipment of a nuclear power plant, which often falls into repair shops. Failures leading to an increase of valve leakage are especially dangerous for nuclear power plants. In this case, leakage of high-pressure valves leads to erosion of the sealing surfaces, which only increases the leakage. Thus, it is very important to determine the optimum rotational value when the valve is closed. The lack of conditions for closure force in the standards for valve leakage complicates the issue.

A bench that allows working in the air with a pressure up to $3.5 \mathrm{MPa}$ was developed on valve rod to study dependence of valve leakage on the rotational moment. Four independent parameters were measured: air pressure in front of the valve under study, closure force of the valve, volume of air loss through the valve and leakage time. A standard stop valve with a nominal diameter of $15 \mathrm{~mm}$ and a nominal pressure of 64 atm was used for the study.

The determined dependence of the leakage on torque value allows recommending a gentler mode of valve closure without significantly reducing its tightness. As a result of experimental data processing, a criterial equation is obtained linking a leakage rate, pressure drop on the valve and a rotational moment value. The received criterial equation will allow defining the compromise between valve closure force and permissible leak level according to regulatory requirements. The analysis of the "leakage/rotational moment" diagram showed the possibility to reveal the damaged valves. This possibility may be used during the incoming inspection of the valves supplied to NPP, which should significantly improve the reliability of their operation.
\end{abstract}

Ke y wo rds: reliability, valves, tightness, closure force, experimental research, criterial equation.
(C) A. V. Korolev, P. Y. Pavlyshyn, I. V. Bandurko, 2018
Any failure of tightness may lead to termination of performance of some individual system. And in the worst case it may cause a major accident like the one that happened at the Three Mile Island NPP in 1979.

According to GOST 9544, the valve tightness is monitored by leak amount depending on the nominal pressure and diameter, while the closure force is set by performance specifications (PS) and design documents (DD) for the item.

It is obvious that amount of leak is largely determined not only by actuating medium parameters (density, viscosity, temperature, etc.) but also by the valve closure force, namely its "minimal" flow cross section. The closure force, which is actually the force pressing the valve cap to the seat, is set by the rotational moment applied to the valve's stem. Limiting clutches of the electric drives are adjusted to a particular rotational moment value that was set at the manufacturer's site. Here arises quite a reasonable question of how optimal is the choice of any taken rotational moment value which is the criterion of selecting this parameter for precise type of valves. Analyses of relevant literature show that no practical research is being carried out in that area, and that the subject is practically not addressed in reference books. In this way, it seems to be important to investigate the dependence of power setpoints valves' leakage rate on the value of the rotational moment applied during their closure.

Experimental setup and experimental procedure. A special test bench capable to perform leakage tests of valve seal in compliance with GOST 5762-2002, has been constructed for this experimental research. The test bench schematic diagram is shown in Fig. 1.

The tested valve 1 was fixed in the test bench between two sealing flanges with rubber gaskets. Bleed air was supplied from one side (under the cap) from compressor 3. The test bench was equipped with AK-50 compressor creating the set pressure in 10-liter receiver 4 , where from the compressed air was further supplied to valve 1 . After passing this valve the air with about atmospheric pressure was directed to the measuring bulb 8 which was submerged under the water in the tank. The volume of the leak was defined by the volumetric method. Two bulbs with measuring limits of $0 \ldots 500 \mathrm{ml}$ and $0 . .5 \mathrm{ml}$ were used for extending the range of measurements and improving their accuracy. Pressure control and measurement in front of the valve were executed by an exemplary gage MO 5 with accuracy class 0.2 . The air temperature was monitored by a mercury thermometer with accuracy within $0.5^{\circ} \mathbf{C}$. The time was measured by an electronic stopwatch with at least $0.1 \mathrm{sec}$ accuracy level.

Measurements of rotational moment values were taken by a torque wrench KD-200-13 [2], enabling to measure rotational moments within the $0 . .250 \mathrm{~N}$ Ym range and accuracy class 2 .

As the valve to be tested, there was used a lock valve manufactured by the "Krasnyi Kotelshchik" Taganrog Boiler Plant (TBP) with the following characteristics: internal flow diameter $d_{0}=10 \mathrm{~mm}$; design pressure $\mathrm{P}_{d}=1.6 \mathrm{MPa}$ (Fig. 2).

The method of the experiment included the following steps. The valve was preliminary opened in order to ensure a guaranteed cap tear off from the seat. Then the valve was tightened by the torque wrench up to the set rotational moment value. After that the compressor was switched on and it increased the pressure up to the set value. The leak was passing through 


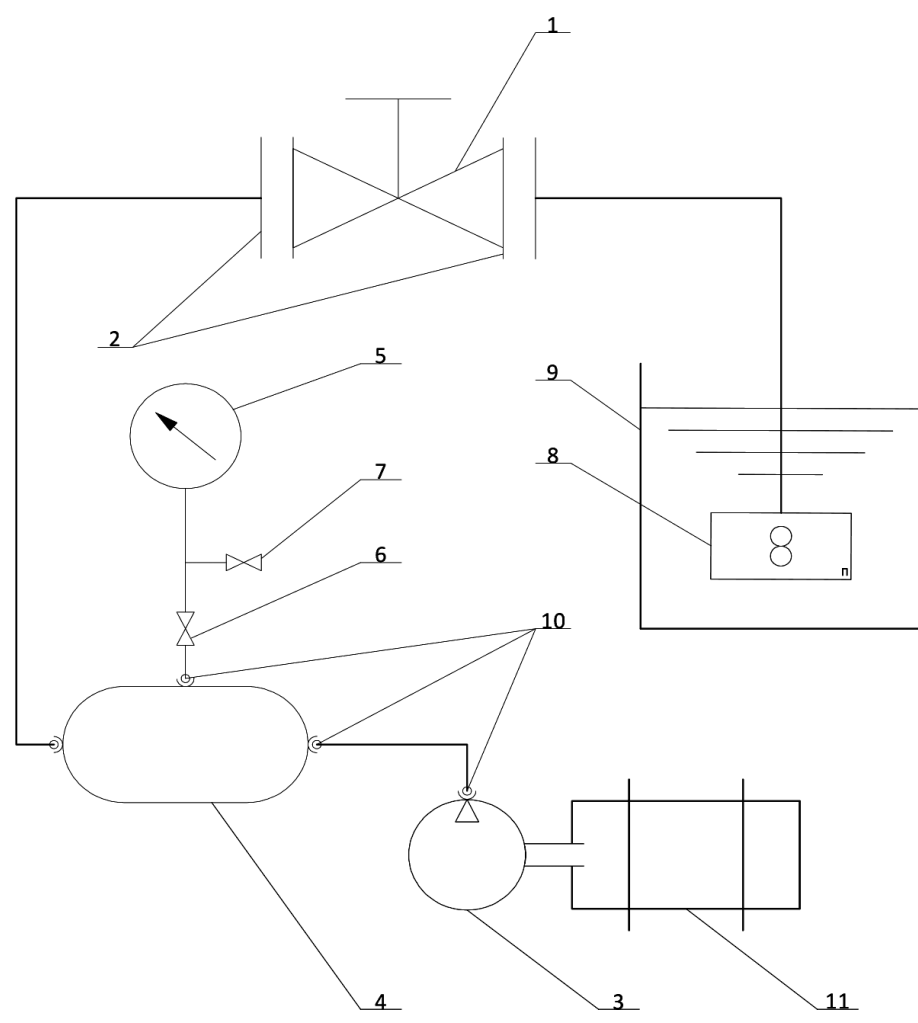

Fig. 1. Schematic diagram of experimental test bench "Power valve leakage test":

1- tested lock valve; 2 - sealing system; 3 - piston compressor; 4 - accumulating vessel (receiver); 5 -exemplary gage; 6 - gage main valve; 7 - gage blow-off valve; 8 - measuring bulb; 9 - water tank; 10 - releasable connection of "ballcone" type; 11 - electric motor

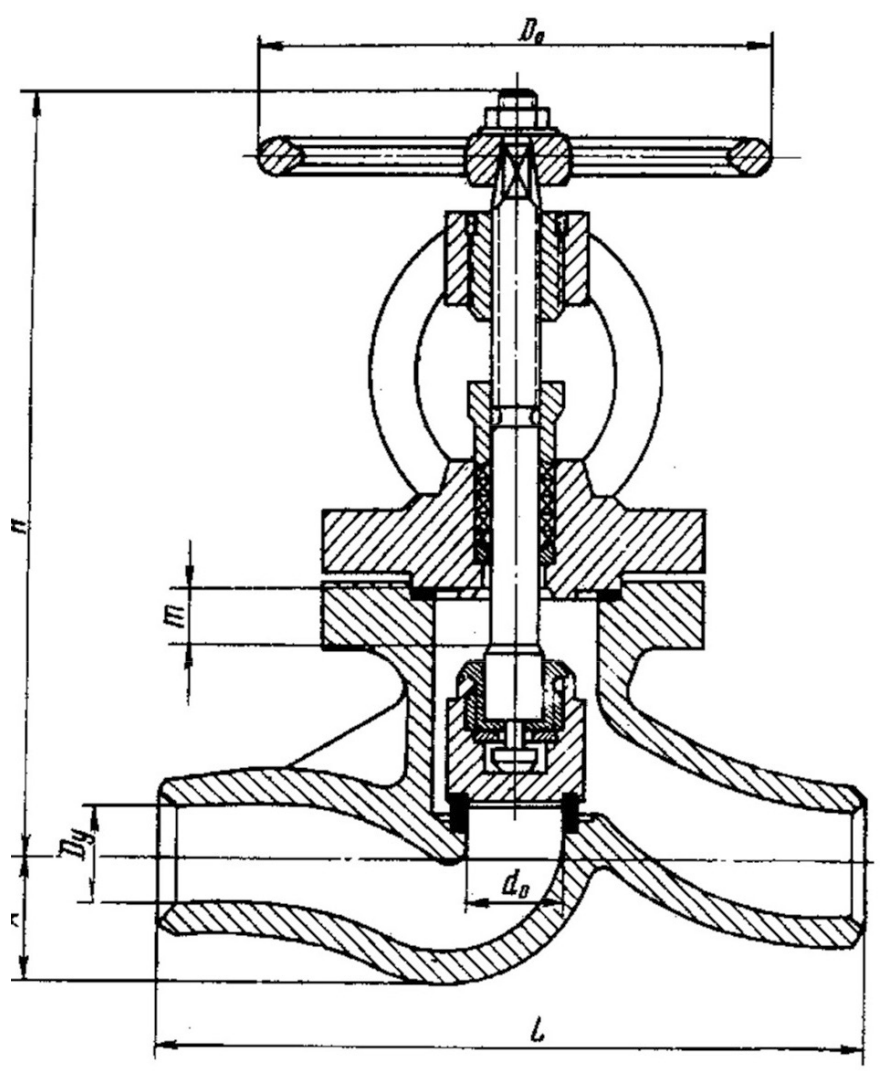

Fig. 2. Schematic design of the tested valves the valve all this period providing the condition for stabilization of the flow through the valve's flow cross section. Then the air was re-directed into the measuring bulb and at that instant the stopwatch was switched on.

In the course of a series of experiments, the leakages through the valve were investigated in the following range of parameters: differential pressure: up to $1.6 \mathrm{MPa}$; rotational moment: up to $40 \mathrm{~N} \cdot \mathrm{m}$ and discharge of air brought to atmospheric parameters up to $165 \mathrm{mmHg}$ (millimeter of mercury scale).

Processing and interpretation of experimental data. The results of all blow-offs of the valve are reflected in the dependence shown in Fig. 3.

The derived diagrams show that all the points are located on the curves of power functions in the co-ordinates of rotational moment - leakage. However, bringing of all data to one diagram shows a large dispersion (Fig. 3) which was quite expected. An analysis of relevant literature has shown the absence of criteria dependences binding all influential parameters, and that has revealed a necessity to derive a criterion that would include all parameters determining the amount of valve leakage.

The following parameters were chosen for experimental data processing: discharged air volume: $Q$, differential pressure of the valve: $\Delta P$, valve flow cross section: $D$, air density: $\rho$, air viscosity: $v$, time: $T$ and rotational moment value: $M$.

$$
Q=\left(\Delta P^{a}, D^{b}, \rho^{c}, v^{d}, T^{e}, M^{j}\right) .
$$

The upper indices are unknown values of the exponents that are in the process of bringing the equation to the criterial form.

The ratio analysis (1) by methods of dimensional theory at the replacement of the dependent parameters has shown that an optimal solution will be obtained in determining a criteria dependence in the form of:

$$
Q / \sqrt{\Delta P}=C \cdot M^{g},
$$

where $\mathrm{C}$ is a coefficient determined by design of the valves, as well as by thermal-physical properties of the actuating medium. It is to be determined experimentally for each type of the valves.

Processing of the experimental data on the dependence (2) allowed deriving a criteria dependence describing an experiment with correlation 0.91 :

$$
Q=\mathrm{C} \cdot \Delta P^{0,5} \cdot M^{-2,17}
$$

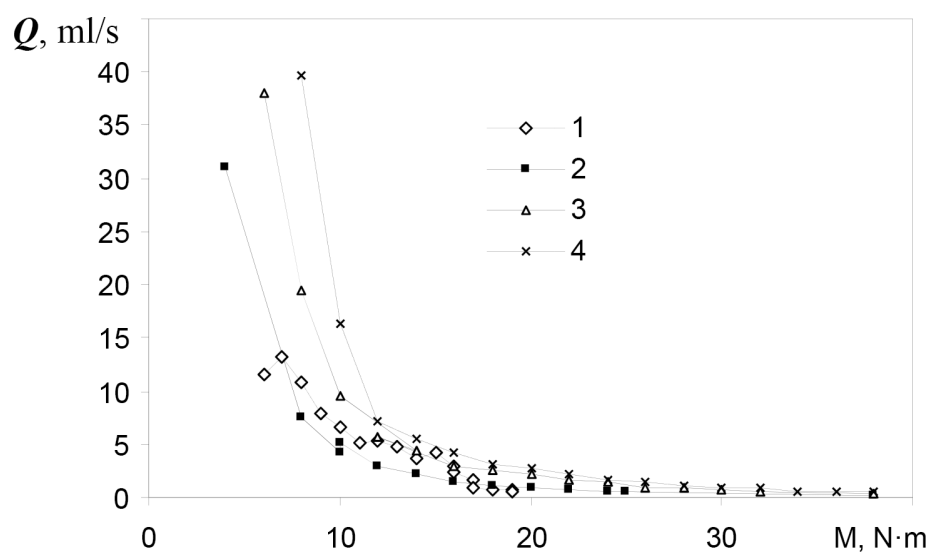

Fig. 3. Dependence of leakage on the rotational moment value at constant pressure: $1-0.405 \mathrm{MPa} ; 2-0.81 \mathrm{MPa} ; 3-1.22 \mathrm{MPa} ; 4-1.62 \mathrm{MPa}$ 


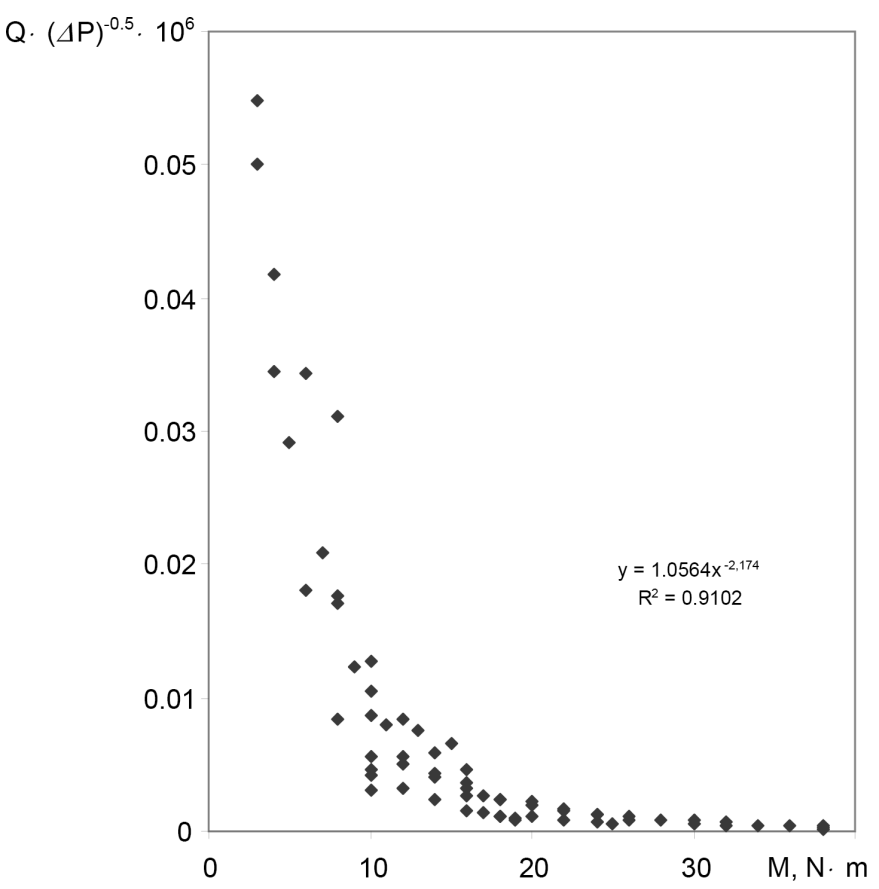

Fig. 4. Dependence of the valves relative leakage on the rotational moment value in valves closure

The derived dependence allows achieving more precise rotational moment adjustment in electric drives. As can be seen in Fig. 4, with regard to this valve, influence of a rotational moment within the range of $32 \ldots 38 \mathrm{NUm}$ is not so sufficient on the amount of leak and therefore, it may be decreased in correlation with the minimum acceptable leak in compliance with the current GOST.

According to the Central Bureau of Valve Design (CBVD) information, an exceeding of valve closure rotational moment during its adjustment only for $17 \%$ of the normalized value leads to reduction of the valve service life in 1.5 times. Not all NPP valves are used for operation at nominal parameters. In this connection, if the pipeline is designed for the pressure less than the valve calculated pressure, then in order to extend valve service life it is possible to adjust the drive according to derived formula for the force less in value than it is set in PS (performance specifications) and DD for this item, which correspondingly will prolong its service life with providing required tightness. The above presented research method enables to identify defects

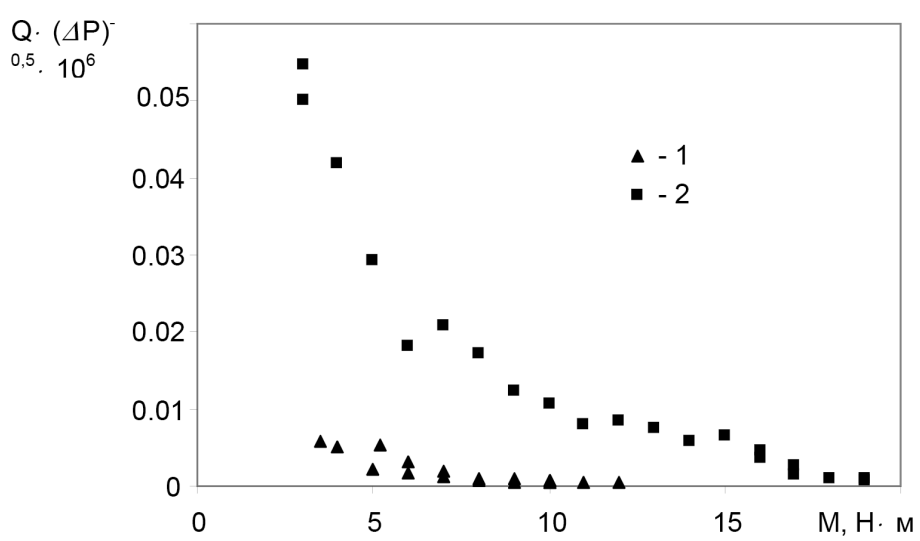

Fig. 5. Dependence of a relative valve leak on the value of the rotational moment during valve closure: 1 - fit faucet; 2 - unfit faucet of the valve flow area. Here appears an opportunity to identify the defects which is difficult to diagnose by examination, the defects related to valve tightness problems.

Thus, in the course of the experiment on one of the lock valves, the empiric data scattered with the projected calculated ones (Fig. 5). A disassembly of the valve showed that the locking pin had got torn off and the locking element did not have rigid connection with the stem, which had led to the above mentioned faults. So it turned out that at small air pressure $(0.4 \mathrm{MPa})$ in one case the cap was lifted by the stem and was bleeding air (Fig. 5, pos. 1) but in the other case it stuck and was lifted by air pressure (Fig. 5, pos. 2). It should be noted that during the experiment on the defective valve, we have got the result that could meet the requirements of GOST 9544 on tightness, and this item could have been accepted usable while the defect would have been revealed only in the course of the valve operations.

\section{Conclusions}

The completed research allows making the following conclusions:

1. There has been obtained a dependence that enables to estimate, with accuracy required in hydrodynamics, the value of a leak at any set rotational moment and referential pressure in the valves.

2. The elaborated method of valve leakage test enables to cast out valves with manufacturer's defects in the most hardto-reach part of the valve: its flow area.

3. The derived dependence is the first one that binds hydrodynamic parameters with valve operating setpoints.

The work done is the first experience in the series of research on power valve leakages that are being carried out in ONPU and is intended to seek and try new methods for on-line control of power valve reliability.

\section{Reference}

1. Gurevich D.F., Shyriaev V.V., Pajkin I.H. (1982). Valves of Nuclear Power Plants [Armatura atomnykh elektrostantsyi], Moscow, Energoizdat, $312 \mathrm{p}$.

2. Torque Wrench KD 200-13, available at: http://www.irand.ru/ shopitem.php?gr $=44 \& \mathrm{gd}=109$

3. Dobrov A.V. (2008), The Method of Diagnosing Electric Drive Valves with the Control of Diagnostic Parameters and Experience of its Application at Smolensk NPP. [Metod diagnostirovania elektroprivodnoj armatury s kontrolem diagnosticeskich parametrov i opyt iego primenenia na Smolenskoj AES]. Armaturostroienie, No. 1(52), pp. 52-60.

\section{А. В. Королёв, П. Я. Павлышин, И. В. Бандурко}

Одесский национальный политехнический университет, г. Одесса, Украина

\section{Экспериментальное исследование герметичности} арматуры при различных усилиях закрытия

Силовая арматура установлена практически на всехтрубопроводах АЭС, выполняя функции регулировки и перекрытия потока, потому ее отказ часто приводит к аварийным ситуациям. Особенно большое количество отказов характерно для электроприводной арматуры. Неправильная настройка предельной муфты приводит 
либо к неполному закрытию арматуры, либо к поломке штока. Поэтому арматура является тем оборудованием АЭС, которое чаще всего попадает в ремонтные мастерские. Особенно опасны для АЭС поломки, приводящие к увеличению утечки арматуры. При этом протечка арматуры высокого давления приводит к эрозии уплотнительных поверхностей, что в свою очередь только увеличивает протечку. Таким образом, очень важно знать оптимальное значение крутящего момента при закрытии арматуры. Усложняет проблему отсутствие в стандартах на протечку арматуры условий на усилие ее закрытия.

Для исследования зависимости протечки арматуры от крутящего момента на ее штоке был разработан стенд, позволяющий работать на воздухе с давлением до 3,5 МПа. Проведены измерения четырех независимых параметров стандартного запорного клапана с условным диаметром 15 мм и условным давлением 64 атм: давления воздуха перед исследуемым клапаном, крутящий момент закрытия клапана объема потери воздуха через арматуру и времени протечки.

Установленная зависимость утечки от величины крутящего момента позволяет рекомендовать более щадящий режим закрытия арматуры без существенного снижения ее герметичности. В результате обработки экспериментальных данных получено критериальное уравнение, связывающее величину протечки, перепад давления на клапане и величину крутящего момента, которое позволит определять компромисс между усилием закрытия арматуры и допустимым уровнем протечки согласно нормативным требованиям. Анализ графика “утечка -крутящий момент» показал возможность определения поврежденной арматуры, что может быть использовано на входном контроле поступающей на АЭС арматуры и существенно повысит надежность ее работы.

Ключевые слова: надежность, арматура, герметичность, усилие закрытия, экспериментальное исследование, критериальное уравнение.

\section{О. В. Корольов, П. Я. Павлишин, І. В. Бандурко}

Одеський національний політехнічний університет, м. Одеса, Україна

\section{Експериментальне дослідження герметичності арма- тури за різних зусиль закриття}

Силова арматура встановлена практично на всіх трубопроводах $A E C$ виконуючи функції регулювання й перекриття потоку, тому ї̈ відмова часто призводить до аварійних ситуацій. Особливо велика кількість відмов спостерігається в електроприводній арматурі. Неправильне налаштування граничної муфти призводить або до неповного закриття арматури, або до поломки штока. Тому арматура є тим обладнанням AEC, яке найчастіше потрапляє в ремонтні майстерні. Особливо небезпечні для AEC поломки, що призводять до збільшення протікань арматури. При цьому протікання арматури високого тиску призводить до ерозії поверхонь ущільнювачів, що свою чергу тільки збільшуе протікання. Таким чином, дуже важливо знати оптимальне значення крутного моменту при закритті арматури. Ускладнює проблему відсутність у стандартах на протікання арматури умов на зусилля ії закриття.

Для дослідження залежності величини протікання арматури від величини крутного моменту на ї̈ штоку був розроблений стенд, що дозволяє працювати на повітрі з тиском до 3,5 МПа. Проведено вимір чотирьох незалежних параметрів стандартного запірного клапана з умовним діаметром 15 мм і умовним тиском 64 атм: тиску повітря перед досліджуваним клапаном, зусилля моменту закриття клапана, об'єму втрати повітря через арматуру і часу протікання.

Встановлена залежність витоку від величини крутного моменту дає змогу рекомендувати більш щадний режим закриття арматури без істотного зниження їі герметичності. B результаті обробки експериментальних даних отримано критеріальне рівняння, що зв'язуе величину протікання, перепад тиску на клапані та величину крутного моменту, за допомогою якого можна визначати компроміс між зусиллям закриття арматури і допустимим рівнем протікання згідно з нормативними вимогами. Аналіз графіка "витік - крутний момент» показав можливість визначення пошкодженої арматури, що може бути використано на вхідному контролі арматури, яка надходить на AEC і суттєво підвищить надійність її роботи.

Ключові слова: надійність, арматура, герметичність, зусилля закриття, експериментальне дослідження, критеріальне рівняння. 